\title{
Bibliometric Analysis of the Literature on Marine Mucilage
}

\author{
Taha Talip Türkistanli ${ }^{1^{*}}$, Coşkan Sevgili ${ }^{2}$, Ömer Arslan ${ }^{2}$ \\ ${ }^{1 *}$ Mersin University, Faculty of Maritime, Maritime Transportation and Management Engineering, Mersin, Turkey, (ORCID: 0000-0003-4903-6138), \\ t.turkistanli@hotmail.com \\ ${ }^{2}$ Dokuz Eylul University, Maritime Faculty, Department of Marine Transportation Engineering, Izmir, Turkey, (ORCID: 0000-0003-3929-079X), \\ coskan.sevgili@deu.edu.tr \\ ${ }^{2}$ Dokuz Eylul University, Maritime Faculty, Department of Marine Transportation Engineering, Izmirl, Turkey, (ORCID: 0000-0002-0623-6714), \\ omer.arslan@deu.edu.tr
}

(1st International Conference on Applied Engineering and Natural Sciences ICAENS 2021, November 1-3, 2021)

(DOI: $10.31590 /$ ejosat.1012189)

ATIF/REFERENCE: Türkistanl1, T., T., Sevgili, C. \& Arslan, Ö. (2021). Bibliometric Analysis of the Literature on Marine Mucilage. European Journal of Science and Technology, (28), 947-958.

\begin{abstract}
Marine mucilage or sea snot is one of the intensely seen environmental problems that increase with the global warming and pollution. In recent years, marine mucilage that especially occurs in inland seas and gulfs has increased both in incidence and intensity in Turkish seas. In this context, this study aims to provide benefits to researchers who will work in this field by analyzing the literature on marine mucilage. A total of 108 academic publications indexed on "Web of Science" database on marine mucilage were analyzed by text mining and bibliometric analyzes using the Vosviewer 1.6.17 program. Analysis results about authors, institutions, and countries of the authors, keywords, citations, abstracts, and regions of the research are presented with descriptive statistics and visual graphics. Findings show that most studies on marine mucilage are published by Italian researchers and researchers at the Rudjer Boskovic Institute (Croatia). When the keywords were analyzed, it was seen that the most frequently used words were "mucilage" and "Adriatic Sea". Text mining conducted on the abstracts of the publications showed the most striking and interacting words as "species", "production" and "summer". As a comprehensive literature review on this subject, this study could act as a starting point for researchers who will work in this field.
\end{abstract}

Keywords: Mucilage, Sea Snot, Mucilage Aggregation, Adriatic Sea, Bibliometric Analysis

\section{Deniz Müsilajına İlişkin Literatürün Bibliyometrik Analizi}

$\ddot{0} \mathbf{z}$

Deniz müsilajı veya deniz salyası, küresel ısınma ve kirlilikle birlikte artan, yoğun görülen çevre problemlerinden biridir. Özellikle iç sularda ve körfezlerde meydana gelen deniz müsilajı son yıllarda, Türkiye denizlerinde de görülme sıklığı ve yoğunluğu artmıştır. Bu bağlamda, bu çalışma deniz müsilajı ile ilgili literatürü analiz ederek bu alanda çalışma yapacak araştırmacılara fayda sağlamayı amaçlamaktadır. "Web of Science" veri tabanında deniz müsilajı ile ilgili indekslenen toplam 108 akademik yayın, Vosviewer 1.6.17 programı kullanılarak metin madenciliği ve bibliyometrik analizlerle analiz edilmiştir. Yazarlar, yazarların kurumları ve ülkeleri, anahtar kelimeler, alıntılar, özetler ve araştırmanın bölgeleri ile ilgili analiz sonuçları betimsel istatistikler ve görsel grafiklerle sunulmaktadır. Bulgular, denizdeki müsilaj üzerine yapılan çalışmaların çoğunun İtalyan araştırmacılar ve Rudjer Boskovic Enstitüsü'ndeki (Hırvatistan) araştırmacılar tarafından yayınlandığını göstermiştir. Anahtar kelimeler incelendiğinde en sık kullanılan kelimelerin "müsilaj" ve "Adriyatik Denizi" olduğu görülmüştür. Yayınların özetleri üzerinde yapılan metin madenciliği, en çarpıcı ve etkileşimli sözcüklerin “tür”, “üretim” ve "yaz” olduğunu göstermiştir. Bu konuda kapsamlı bir literatür taraması olarak bu çalışma, bu alanda çalışacak araştırmacılar için bir başlangıç noktası olabilir.

Anahtar Kelimeler: Müsilaj, Deniz Salyası, Müsilaj Toplama, Adriyatik Denizi, Bibliyometrik Analiz 


\section{Introduction}

Mucilage is a gel-like structure formed by the combination of different environmental conditions and sea creatures such as phytoplankton and microalgae [1]-[3]. This structure, also known as marine snow or sea snow, occurs in calm, unmixed marine environments as a result of the disruption of production and consumption balance [1], [2], [4]. Studies list many reasons for marine mucilage. Some of these can be listed excessive proliferation of marine organisms, the complete disappearance of small fish species, the lack of proper agricultural practices, the discharge of city wastewater into the sea without treatment, the mixing of factory wastes into the water, and the increase in the average temperature in the seas [1], [5]. This gel-like structure, which is formed by many triggers, causes economic losses through fishing and tourism, as well as ecological and sociological losses [2], [5].

Marine mucilage, which was first seen in the Adriatic Sea in the 1700s [6], [7], was later seen in many seas [3], [8]. Since then, many studies [6], [7], [9]-[13] have been carried out on mucilage, from researching the main causes of mucilage to spreading. There are even studies of synthetic mucilage obtained in the laboratory environments [14]-[16].

With this study, the studies carried out in the literature were examined and their relations with each other, the countries, authors, journals and institutions that made the most publication, the most used words, and relationship networks, and which authors worked in this field were examined. Thus, an attempt was made to assist future studies. In addition, with the information it contains, it is possible to show the most studied parts to the authors who want to work in this field and to notice the less studied areas.

\section{Materials and Method}

In order to analyze literature on marine mucilage, Web of Science (WOS) database was used in September 2021. All of the index criteria in the database (SCI-EXPANDED, SSCI, A\&HCI, CPCI-S, CPCI-SSH, ESCI, BKCI-SSH, BKCI-S) was included in the searches. To determine all publications related to this study, the time span was not selected in the database. The literature search terms were applied as; theme $=$ (marine) AND (mucilage) AND (sea) in topics. Searches done with "topic" include title, abstract, author keywords, and keywords plus. The data was extracted from WOS database as a text file (*.txt) and imported to VOSviewer software.
VOSviewer is a Java-based computer program developed for creating, visualizing, and exploring bibliometric maps of science. It creates maps based on related data and for visualizing and exploring the maps [17], [18]. Publication maps, country maps, journal maps, keyword maps are some of the maps created by the software. Software permits adjustment of the frequency of keywords in the dataset as desired and keywords with a low frequency can be removed from analysis if wants. Also, VOSviewer makes data mining analyses such as mining abstracts of publications and grouping articles [19].

VOSviewer was used for analyzing and visualizing keywords, citations, authors, institutions, and countries of authors in this study. In addition, relationships and relevancies in abstracts of publications were analyzed with the data mining approach. More detailed reviews on the methods and study areas were then conducted manually.

\section{Findings}

Database search with given keywords was resulted in 250 articles found on to mucilage subject. These articles were then analyzed extensively according to their subject and field. Out of 250 articles, 142 were found to have weak relevance or no direct connection to marine mucilage. This result was expected as it was due to the use of broader search terms to not overlook any relevant studies in the searches. Therefore, an elimination process was carried out and articles that are not related to marine mucilage were excluded from the data set. Thus, the final dataset consists of 108 publications on marine mucilage.

\subsubsection{Findings on the Publication Years}

There is a total of 108 studies conducted between the years 1993 and 2021 (Figure 1). Even though there are studies on marine mucilage before 1993 our limits on methods and therefore data do not include those publications.

The distribution of marine mucilage publications displays sudden spikes between specific years. The first major increase in studies is seen between the years 1994 and 1997. This was then followed by an abrupt increase in 2005 . The highest study count after these years was in 2016. We see a downtrend following the year 2016. Study counts keep declining past these peak years and even dropping below two articles for a year, only to climb back up for another time period. This finding indicates that studies seem to increase with potential mucilage outbreaks.

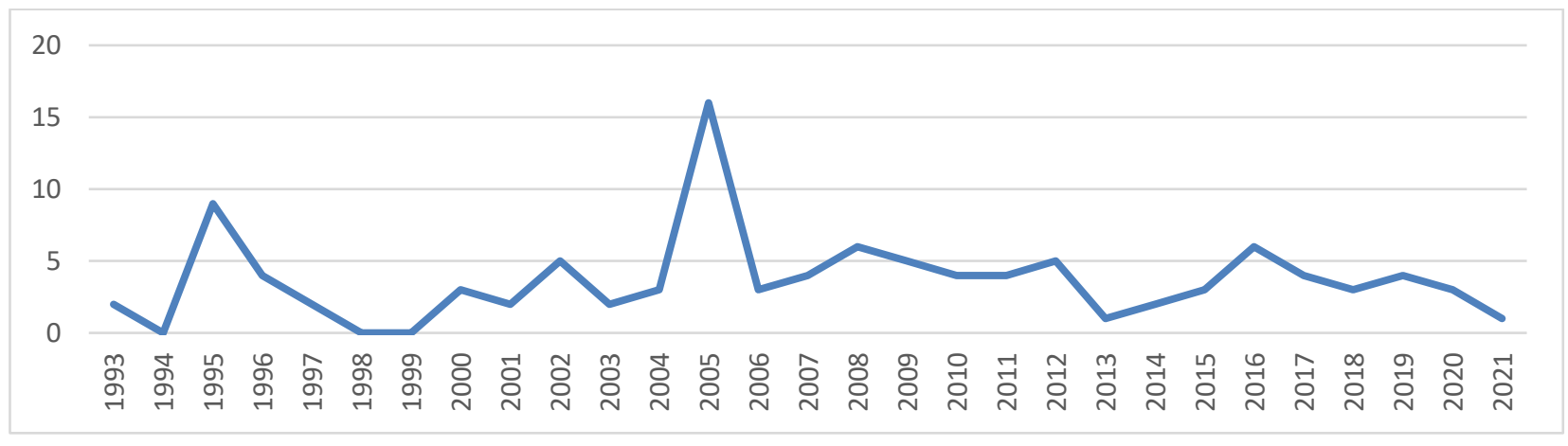

Fig. 1 Distribution of articles by year of publication 
Table 1. Analysis Results of Authors

\begin{tabular}{|c|c|c|c|c|}
\hline Name of Author & $\begin{array}{c}\text { Number of } \\
\text { Publications }\end{array}$ & $\begin{array}{c}\text { Number of } \\
\text { Citations }\end{array}$ & $\begin{array}{c}\text { Average Citations } \\
\text { per Publication }\end{array}$ & Total Link Strength \\
\hline Giani, M. & 9 & 294 & 32.7 & 29 \\
\hline Mecozzi, M. & 9 & 214 & 23.8 & 16 \\
\hline Urbani, R. & 8 & 191 & 23.9 & 28 \\
\hline Sist, P. & 8 & 215 & 26.9 & 24 \\
\hline Umani, S.F. & 8 & 294 & 36.8 & 21 \\
\hline Berto, D. & 6 & 122 & 20.3 & 19 \\
\hline Svetlicic, V. & 6 & 140 & 23.3 & 19 \\
\hline Zutic, V. & 6 & 140 & 23.3 & \\
\hline
\end{tabular}

\subsubsection{Findings on the Authors of the Publications}

In the analysis of the authorship of the publications, we set a limit of minimum three publications per author. Therefore, only the authors with three or more publications are included in the analysis. This was done for a cleaner presentation of the findings.

We determined the authors who published the most on the subject as, Giani M. and Mecozzi, M. with 9 publications and Urbani, R., Sist, P. and Umani, S. F. with 8 publications respectively (Table 1). According to analysis results, the most cited author was Herndl, G. J. with 367 citations through 3 publications. Giani, M. has the highest total link with 29 links. Total links between authors are shown in Figure 2.

\subsubsection{Findings on the Countries of Publications}

It was seen that publications about marine mucilage have been mostly conducted by authors from Italy. This is respectively followed by Croatia and France. The publications from Italy have also the highest number of citations received. Although the number of publications from Austria is relatively lower than other countries, the number of citations these studies get is ranked in the third place when compared to others (Table 2). It is observed that the publications on marine mucilage from the USA and Austria were mostly before the year 2010. It is seen that the publications from Italy, Croatia, and France were mostly made around the 2010s. In addition to these, it has been found out that studies from Turkey and Greece have only started to focus on this subject in the recent years (Figure $3 b$ ).

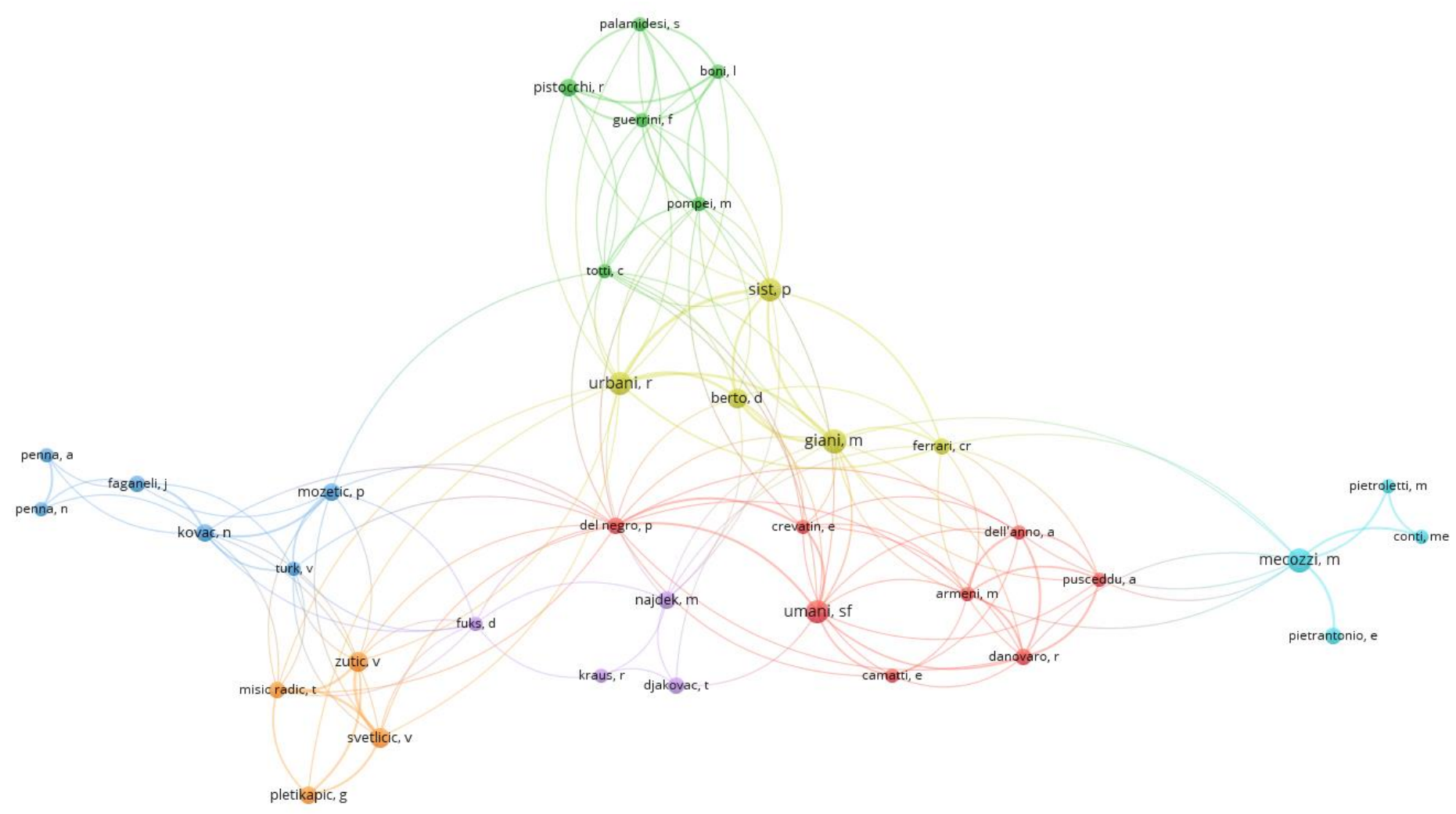

Fig. 2 Mapping the co-authorship on marine mucilage 
Table 2. Analysis Results of Countries of Publications

\begin{tabular}{|c|c|c|c|c|}
\hline Country & $\begin{array}{c}\text { Number of } \\
\text { Publications }\end{array}$ & Number of Citations & $\begin{array}{c}\text { Average Citations } \\
\text { per Publication }\end{array}$ & Total Link Strength \\
\hline Italy & 58 & $\mathbf{1 1 9 8}$ & 20.7 & 16 \\
\hline Croatia & 21 & $\mathbf{5 4 5}$ & 26.0 & 10 \\
\hline France & 8 & 172 & 21.5 & 3 \\
\hline Slovenia & 7 & 85 & 12.1 & 9 \\
\hline USA & 6 & 158 & 26.3 & 8 \\
\hline Greece & 5 & 65 & 13.0 & 4 \\
\hline Turkey & 5 & 55 & 11.0 & 5 \\
\hline Spain & 3 & 70 & 23.3 & 2 \\
\hline Austria & 3 & $\mathbf{3 6 7}$ & $\mathbf{1 2 2 . 3}$ & \\
\hline Canada & 3 & 260 & $\mathbf{8 6 . 7}$ & \\
\hline
\end{tabular}

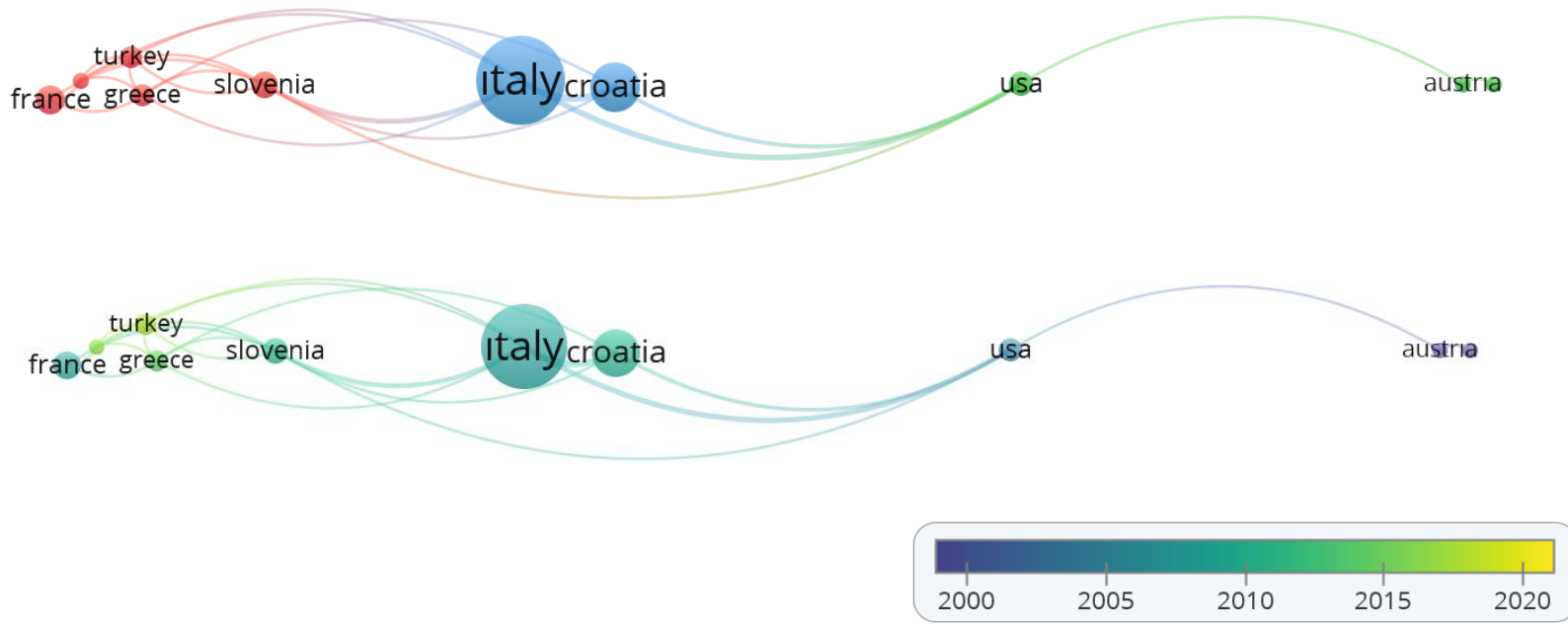

Fig. 3. a Mapping the countries of publications on marine mucilage

3.b Mapping the distribution of the publications of the countries by years

Table 3. Analysis Results of Institutions of Publications

\begin{tabular}{|c|c|c|c|c|}
\hline Institutions/Organization & $\begin{array}{c}\text { Number of } \\
\text { Publications }\end{array}$ & Number of Citations & $\begin{array}{c}\text { Average Citations } \\
\text { per Publication }\end{array}$ & Total Link Strength \\
\hline Rudjer Boskovic Institute & $\mathbf{1 7}$ & $\mathbf{4 6 5}$ & 27.4 & 7 \\
\hline Univ. Trieste & 14 & 395 & 28.2 & 23 \\
\hline CNR & 11 & 376 & $\mathbf{3 4 . 2}$ & 8 \\
\hline Univ. of Bologna & 7 & 137 & 22.6 & 3 \\
\hline $\begin{array}{c}\text { Ist Cent. Ric. Sci \& } \\
\text { technol Applicata }\end{array}$ & 7 & 158 & 13.3 & 3 \\
\hline Natl. Inst. Biol. & 6 & 80 & $\mathbf{3 4 . 2}$ & 12 \\
\hline $\begin{array}{c}\text { Ist. Nazl. Oceanog \& } \\
\text { Geofis Speriment. }\end{array}$ & 5 & 171 & 20.8 & 10 \\
\hline Univ. Politecn. Marche & 5 & 104 & $\mathbf{4 0 . 2}$ & 8 \\
\hline ICRAM & 5 & 201 & 29.3 & 8 \\
\hline Ctr. Ric. Marine & 4 & 117 & 12.8 & 6 \\
\hline Univ. Florence & 4 & 51 & 3.8 & 5 \\
\hline $\begin{array}{c}\text { Marine Protected Area } \\
\text { Tavolara P. }\end{array}$ & 4 & 15 & 8.5 & 2 \\
\hline Univ. Genoa & 4 & 34 & 12.5 & 2 \\
\hline İstanbul Univ. & 4 & 50 & & \\
\hline
\end{tabular}




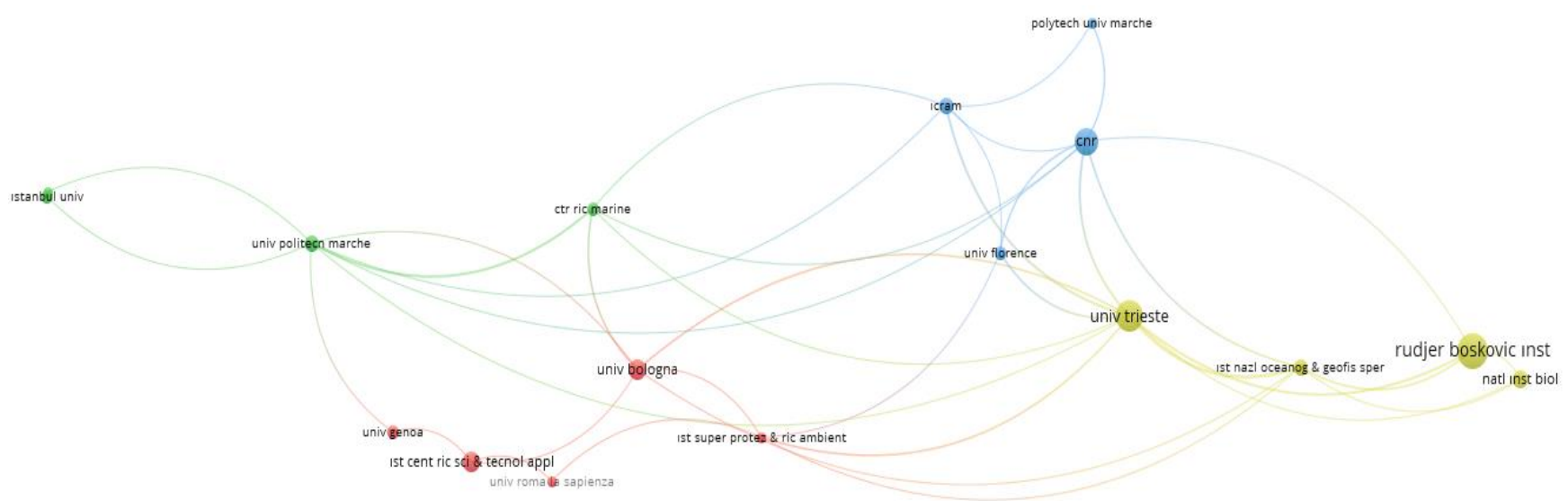

Fig. 4 Mapping on co-authorship of organizations related to marine mucilage

\subsubsection{Findings on the Institutions (Organization) of the Authors}

The affiliated organization of the authors that publishes the most on marine mucilage is the Rudjer Boskovic Institute. Authors from this institute have a total of 17 publications and 465 citations averaging 27.3 citations per article. The University of Trieste, Consiglio Nazionale delle Ricerche (CNR), University of Bologna are other organizations that publish the most with an average of 28.2 and 34.2 citations per article. Although the publication numbers of the ICRAM and Ist. Nazl. Oceanog \& Geofis Speriment are considered relatively low, it was seen that their citation numbers and the average citations per article (40 and 34.2) are quite higher (Table 3). Mapping on co-authorship of the organizations is shown in Figure 4.

\subsubsection{Findings on the Keywords}

The Analysis of the keywords conducted on the 108 publications shows that the most frequently used keywords are "mucilage", "Adriatic Sea" and the "Northern Adriatic Sea". It should also be noted that the "Adriatic Sea" and "Northern Adriatic Sea" are often used as synonyms in these studies. Therefore another most frequently used keyword would be "Mediterranean Sea". In addition to that, due to the high occurrence of Mediterranean and Tyrrhenian Sea as keywords, it can be deduced that the Mediterranean Sea is one of the most significant keywords in the subject of marine mucilage. The country and organization of the authors also coincide with this finding. The other most used keywords and their total link strength are shown in Table 4.

Table 4. Analysis Results of Keywords

\begin{tabular}{|c|c|c|}
\hline Keyword & Occurrence & Total Link Strength \\
\hline Mucilage & 26 & 25 \\
\hline Adriatic Sea & 14 & 13 \\
\hline Northern Adriatic Sea & 12 & 5 \\
\hline Mediterranean Sea & 9 & 5 \\
\hline Phytoplankton & 9 & 7 \\
\hline Nutrients & 8 & 7 \\
\hline Tyrrhenian Sea & 6 & 3 \\
\hline Humification & 5 & 2 \\
\hline Marine Mucilage & 5 & 9 \\
\hline Cylindrotheca Closterium & 5 & 10 \\
\hline
\end{tabular}




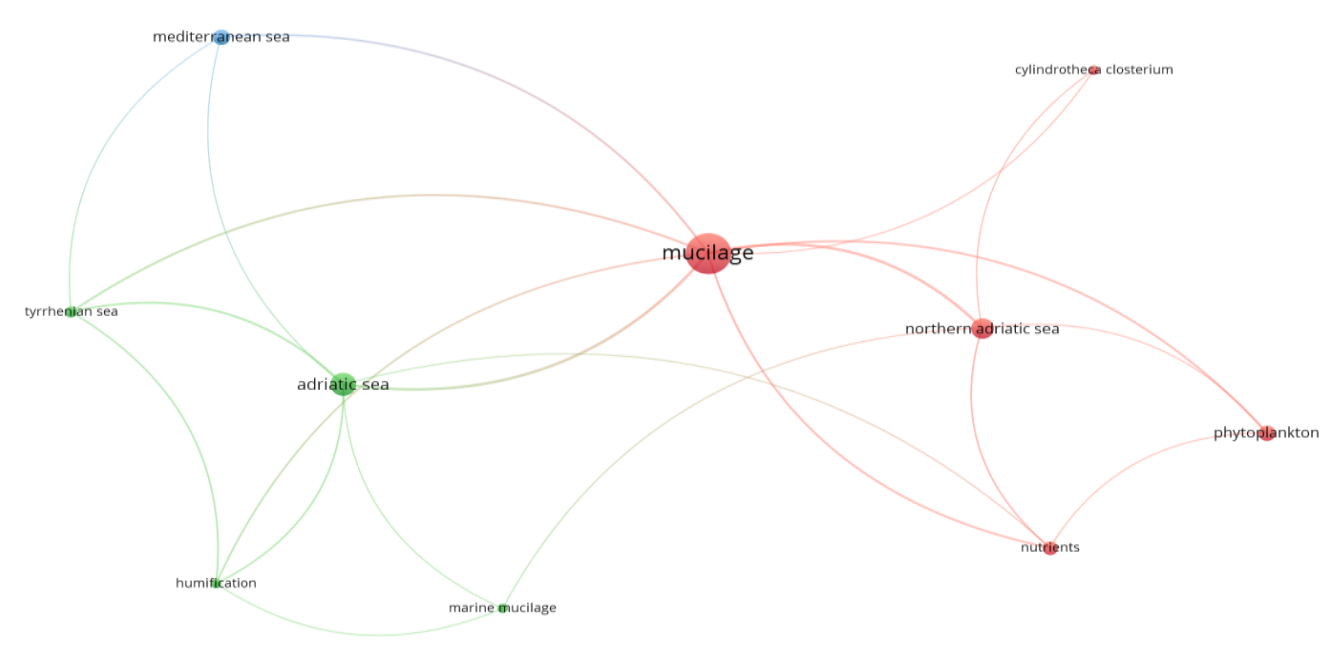

Fig. 5 Mapping on the co-occurrence of keywords related to marine mucilage

\subsubsection{Findings on the Citations and Publication Count}

The In this study, the analysis of citations was made over the journals in which the articles were published. Science of the Total Environment is the most-cited journal with a total of 1208 citations on 22 publications, averaging 26.5 citations per article (Table 5). Marine Ecology Progress Series also stands out among the most cited journals. When the publication citation rate is examined, the journal with the highest average is the Marine Ecology Progress Series with an average of 76.2 citations per article. Following this, Science of the Total Environment has 54.9 average publication citation rate. Likewise, Science of the Total Environment has the highest total link strength with 69 among the journals. The distribution of citations among the journals by the years and their total link strength can be seen in Figure 6 .

\subsubsection{Findings on the Citations of the Authors}

The citation count of the authors was also analyzed in the research. To ease the analysis process and to present cleaner data; a limit of minimum 35 citations per publication has been set. According to analysis results, articles of Myklestad (1995) [28], Obernosterer \& Herndl (1995) [29] and, Thornton (2002) [32] are the most cited publications. The work of Myklestad (1995) was cited 386 times and while being one of the early papers on the subject. This seems pattern seems to follow other highly cited research. Obernosterer \& Herndl (1995) [29] got 242 and Thornton (2002) [32] got 179 citations which both take place in the early years of our dataset.

Table 5. Analysis Results of Citations by Journals

\begin{tabular}{|c|c|c|c|c|}
\hline Journals & Number of Citations & $\begin{array}{c}\text { Number of } \\
\text { Publications }\end{array}$ & $\begin{array}{c}\text { Average Citations } \\
\text { per Publication }\end{array}$ & Total Link Strength \\
\hline $\begin{array}{c}\text { Science of the Total } \\
\text { Environment }\end{array}$ & 1208 & 22 & $\mathbf{5 4 . 9}$ & $\mathbf{6 9}$ \\
\hline $\begin{array}{c}\text { Marine Ecology } \\
\text { Progress Series }\end{array}$ & 381 & 5 & 33.2 & 72 \\
\hline $\begin{array}{c}\text { Estuarine Coastal and } \\
\text { Shelf Science } \\
\text { Marine Chemistry }\end{array}$ & 166 & 5 & 22.9 & 70 \\
\hline $\begin{array}{c}\text { Marine Environmental } \\
\text { Research }\end{array}$ & 160 & 7 & 21.7 & 16 \\
\hline Harmful Algae & 47 & 3 & 15.7 & 12 \\
\hline
\end{tabular}




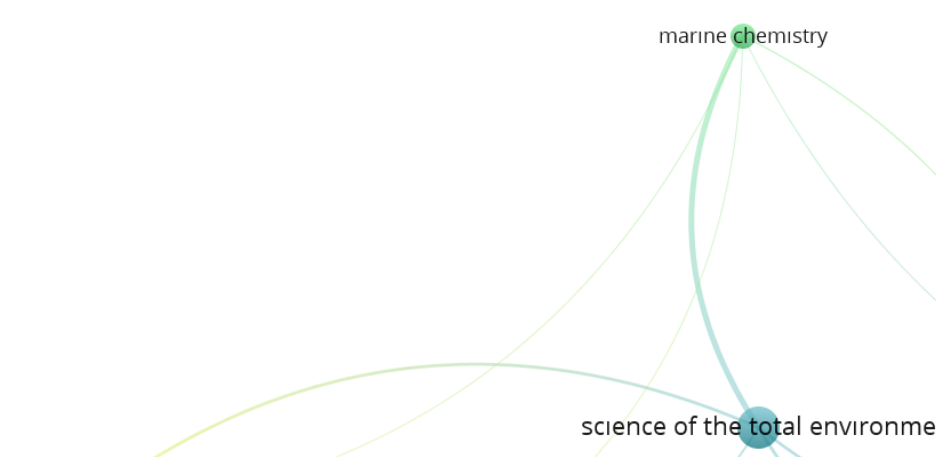

harmful algae

Fig. 6 Mapping on citations of journals by year

Table 6. Analysis Results of Citations by Authors

\begin{tabular}{|c|c|c|}
\hline Authors & Number of Citations & Total Link Strength \\
\hline Myklestad (1995) & 386 & 2 \\
\hline Obernosterer \& Herndl (1995) & 242 & 5 \\
\hline Thornton (2002) & 179 & 2 \\
\hline Leppard (1995) & 134 & 6 \\
\hline Giani (2012) & 80 & 8 \\
\hline Alcoverro (2000) & 77 & 8 \\
\hline Magaletti (2004) & 70 & 6 \\
\hline Danovaro (2009) & 69 & 6 \\
\hline Rinaldi (1995) & 68 & 4 \\
\hline Decho (1995) & 65 & 3 \\
\hline Baldi (1997) & 57 & 1 \\
\hline Alldredge (1995) & 57 & 2 \\
\hline Heissenberger (1996) & 52 & 5 \\
\hline Zaccone (2002) & 51 & \\
\hline Pletikapic (2012) & & \\
\hline
\end{tabular}




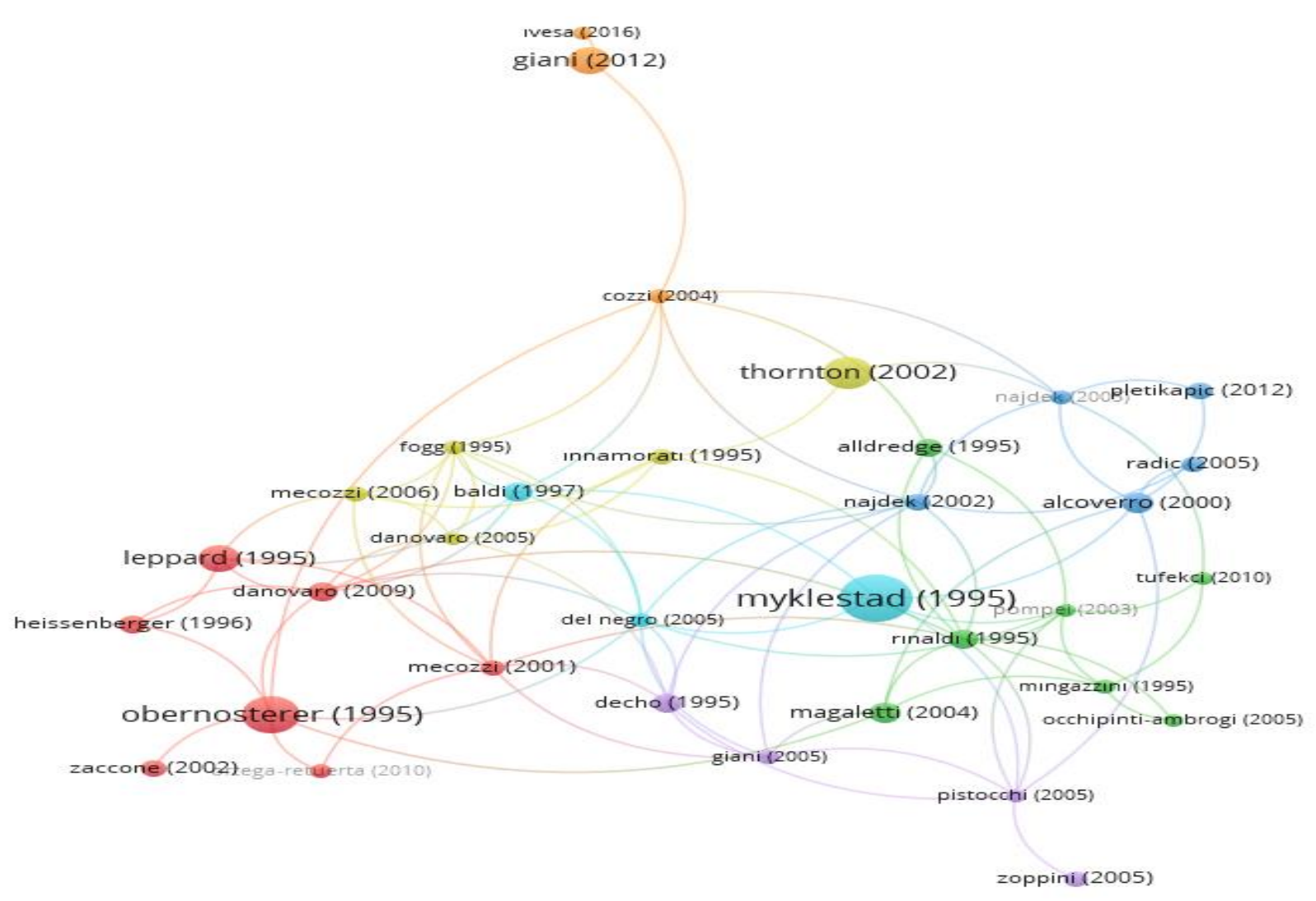

Fig. 7 Mapping on citations of journals by authors

Table 7. Analysis Results of Publications' Abstracts

\begin{tabular}{|c|c|c|}
\hline Term & Occurrence & Relevance \\
\hline Species & 35 & 0.49 \\
\hline Production & 31 & 0.69 \\
\hline Summer & 31 & 0.45 \\
\hline Organic Matter & 30 & 0.89 \\
\hline Formation & 26 & 1.74 \\
\hline Period & 25 & 0.61 \\
\hline Mucilage Event & 23 & 1.07 \\
\hline Change & 23 & 0.75 \\
\hline Bloom & 21 & 1.18 \\
\hline Diatom & 19 & 0.99 \\
\hline Carbohydrate & 18 & 1.65 \\
\hline Mechanism & 16 & 2.60 \\
\hline Polysaccharide & 14 & 1.47 \\
\hline Mucilage Aggregate & 14 & 1.16 \\
\hline Mediterranean Sea & 13 & 1.22 \\
\hline
\end{tabular}




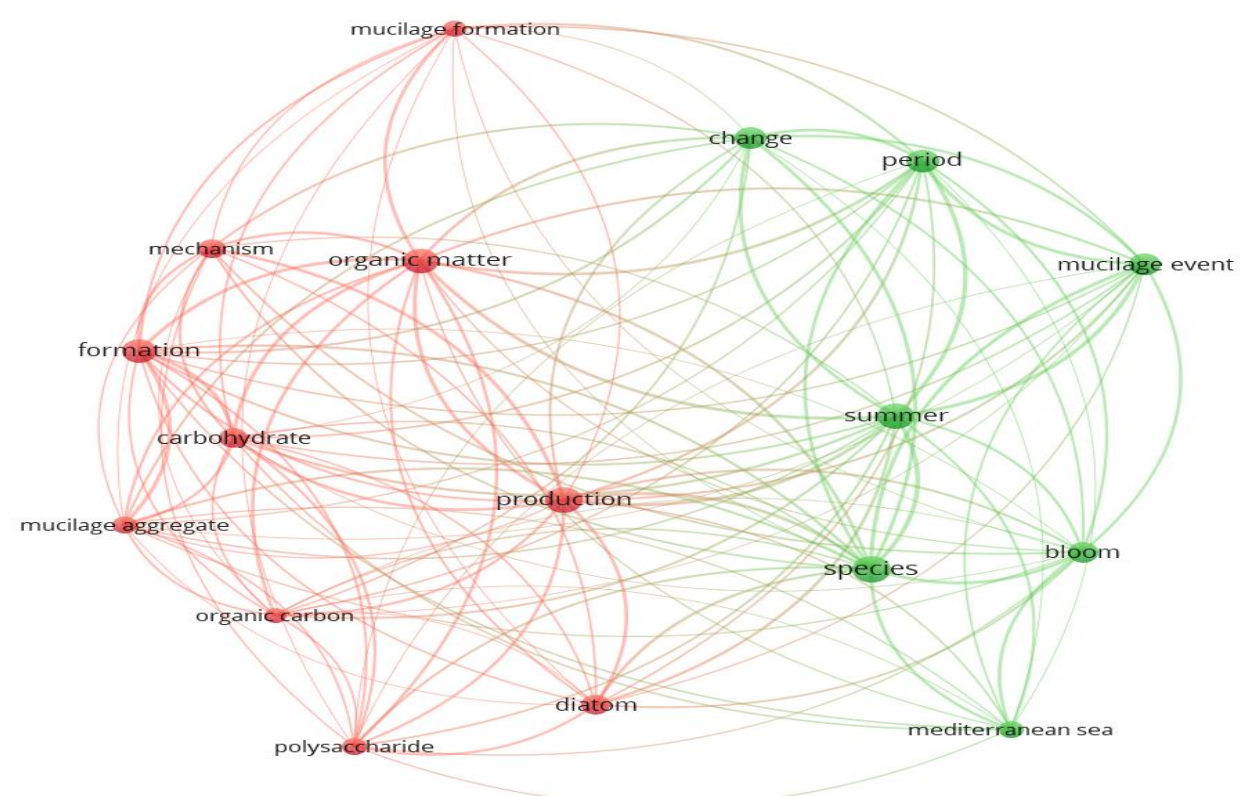

Fig. 8 Mapping on co-occurrence of terms in abstracts

\subsubsection{Data Mining of Abstracts}

Finally, the most frequently used words and word interactions were examined by applying text mining to 108 articles. The minimum number of occurrences of a term was selected as 10 . A total of 24 words were identified that fit this selection, but some words such as "study", "presence", and "sample" were excluded from the analysis. Analysis conducted revealed 17 significant words. The word with the highest occurrence is "species" with the 35 occurrences. "Production", "summer", and "organic matter" are the other words with the highest occurrences (Table 7). These words are grouped around two clusters (red and green) as seen in Figure 8 .

\subsubsection{Research Areas}

Fin In our analysis, we extracted the focus/reference or sampling area of the conducted studies (Figure 9 \& Figure 10).
Findings on these showed that most of the studies were localized within the (Northern) Adriatic Sea. Following this, Tyrrhenian Sea and Gulf of Trieste were the most common areas for marine mucilage research. Considering that these are the names of local waters within a greater body of sea, we can claim that the overall research area for marine mucilage is condensed within the Mediterranean Sea. Considering the other areas for marine mucilage research, we encounter a limited number of studies that focus outside of the Mediterranean Sea. A note to point on these findings are; studies that focus on smaller-scaled areas also try to generalize their finding to a bigger scale. Such as; research that uses samples collected from a gulf or a coast elaborate and connect its findings to a larger sea that the sample area is connected to.

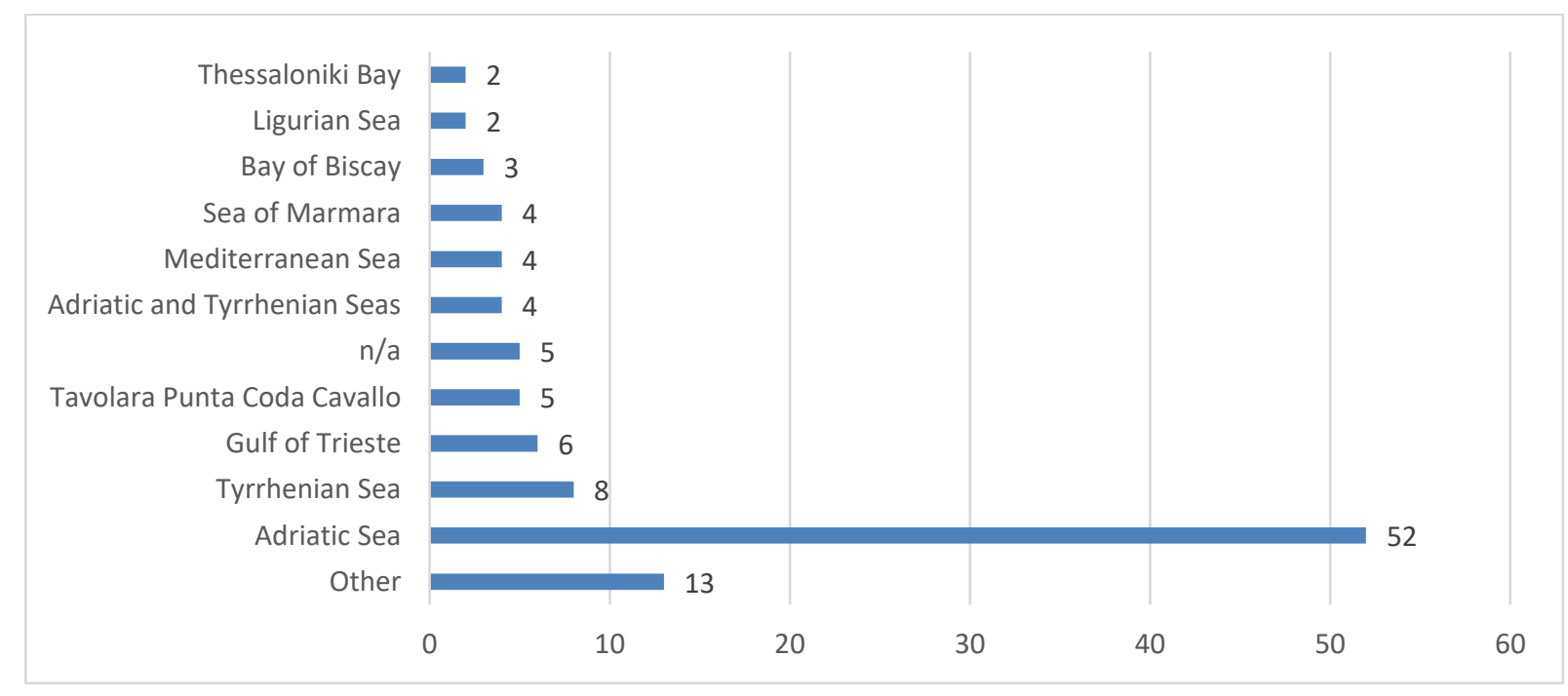

Fig. 9 Area of the referencelfocus/sample of the research 


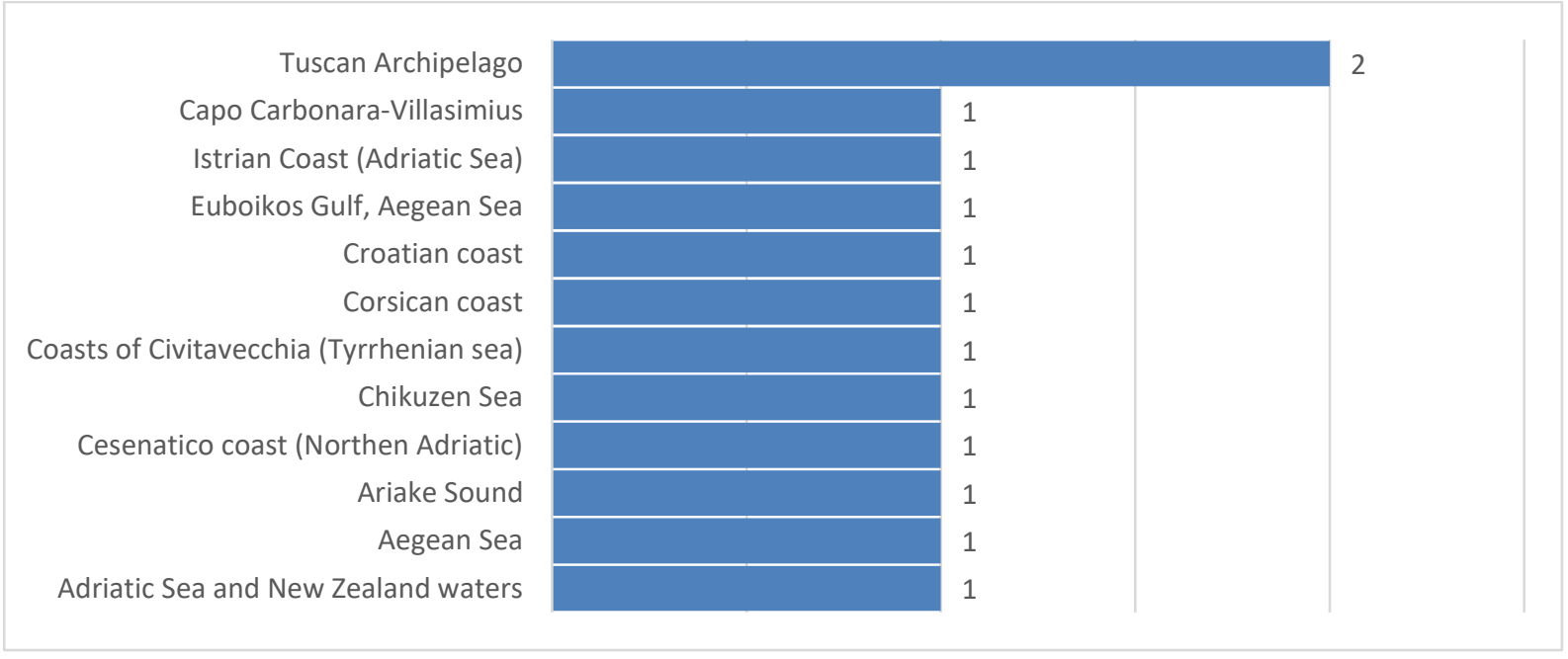

Fig. 10 Area of the referencelfocus/sample of the research (others detailed)

\subsubsection{Research Methods}

The analysis of the adopted research methods was conducted on the general basis of the studies. We considered the aims and overall used methods when classifying the studies. Our finding showed that most of the research was conducted with quantitative research methods in mind (Figure 11). Considering the field of the studies this was an expected result. There are also few studies that adopted qualitative methods and a few that utilized mixed research methods.

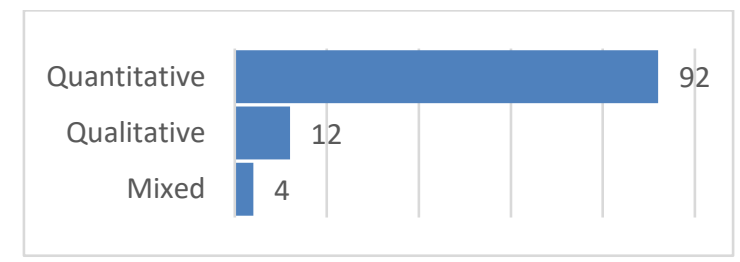

Fig. 11 Adopted Research Methodologies of the Articles

A more detailed analysis showed that most of the quantitative studies adopted correlational, experimental, or comparative methods as a basis and there was no significant distinction between the numbers of these methods (Figure 12). Descriptive researches as explaining and giving info about the current situations in quantitative details were also seen frequently. Review articles condensing, analyzing, and giving an insight into the marine mucilage phenomenon were also available. Theorybuilding methods are mostly seen in the early researches conducted.

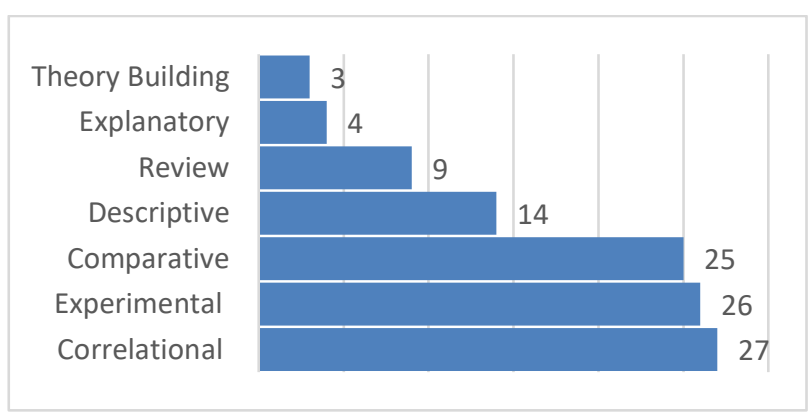

Fig. 12 Detailed Research Methodologies of the Articles

\section{Conclusion}

Even though marine mucilage formations are not new nor unknown events, the importance of them as a research subject seems to increase with eventual occurrences. That means research conducted takes shape according to mucilage events. It is more likely to see an increase in the research on this subject as long as marine mucilage outbreaks keep happening. This case is also confirmed with the focus or reference area of the studies. Most of the studies are directly related to mucilage events in Adriatic and Tyrrhenian Sea. A few different areas focused on studies are the Aegean Sea and the Ligurian Sea which are also close to the aforementioned areas. All of these seas are localized in the Mediterranean Sea. More regional researches that focus on a smaller area also group around the coasts of Italy. Therefore, it is safe to say that the main focus of marine mucilage research is centered and condensed in the Mediterranean Sea. Thus authors, their country of origins, and their affiliated organization are close to these regions. This means marine mucilage problem and solution of it through research actually might be more localized than thought.

Research on marine mucilage frequently tries to establish a correlation and try to determine the causes and the origin of the problem. There are some studies that focus on the solution part but not more than the research that tries to analyze, compare and understand the current situation. This is mostly done through adopting quantitative research methods. Likewise, field studies seem to make up the great majority of the articles. Though it is not possible to make a distinction between experimental, correlational, or comparative studies, it is clear that most of them adopt applied methods in research. Qualitative research studies, on the other hand, fall behind in count but still get a considerable amount of citation as they establish a base for the phenomenon. We see that few of the most cited publications on this subject are review studies that act as a reference for other studies. As for the citations and publication, one journal excels as an important hub for marine mucilage. Journal "Science of the Total Environment" publishes most on this topic, as they cover and encourage multidisciplinary environmental research. Along with the journal "Marine Ecology Progress Series" these two journals make up the biggest citation sources. 
It can be considered that continuing regional studies will support and pave way for future studies and the number of publications on this topic will increase in the number. Additional mucilage events would also increase the importance of this topic. As such the recent mucilage events at the Sea of Marmara and Turkish coasts attracted the attention of the public and the media. This means the importance of regional research may now be even more significant.

\section{References}

[1] TMMOB Çevre Mühendisleri Odası İstanbul Şubesi, 2021, "Marmara Denizi Müsilaj Sorununun Sebepleri, Değerlendirmesi ve Çözüm Önerileri”.

[2] G. Altuğ, M. Çardak \& P. S. Çiftçi. (2010). "Marmara Denizi'nde müsilaj oluşumu ve bakteriyel etkileşimler". “Marmara Denizi 2010” Sempozyumu, 25-26 Eylül 2010, İstanbul.

[3] B. Savun Hekimoğlu \& C. Gazioğlu. (2021). "Mucilage problem in the semi-enclosed seas: recent outbreak in the sea of Marmara". International Journal of Environment and Geoinformatics, 8(4), 402-413.

[4] R. Precali, M. Giani, M. Marini, F. Grilli, C. R. Ferrari, O. Pečar \& E. Paschini. (2005). "Mucilaginous aggregates in the Northern Adriatic in the period 1999-2002: typology and distribution". Science of the Total Environment, 353(1-3), 1023.

[5] ENV Enerji Çevre Yönetimi ve Teknolojileri, (2021), Deniz Salyası (Müsilaj).

[6] R. A. Vollenweider \& A. Rinaldi. (1995). Editorial. Science of the Total Environment, 165, 5-7.

[7] M. E. Conti. (1996). "The pollution of the Adriatic Sea: scientific knowledge and policy actions". International Journal of Environment and Pollution, 6, 113-130.

[8] A. De Lazzari, D. Berto, D. Cassin, A. Boldrin \& M. Giani. (2008). "Influence of winds and oceanographic conditions on the mucilage aggregation in the Northern Adriatic Sea in 2003-2006". Marine Ecology, 29(4), 469-482.

[9] M. Mecozzi, M. Pietroletti, M. Scarpiniti, R. Acquistucci \& M. E. Conti. (2012). "Monitoring of marine mucilage formation in Italian Seas investigated by infrared spectroscopy and independent component analysis". Environmental Monitoring Assessment, 184, 6025-6036. https://doi.org/10.1007/s10661-011-2400-4

[10] J. Berthon, G. Zibordi \& S. B. Hooker. (2000). "Marine optical measurements of a mucilage event in the Northern Adriatic Sea". Limnology and Oceanography. 45(2), 322327. https://doi.org/10.4319/1o.2000.45.2.0322

[11] F. De Angelis, M. V. Barbarulo, M. Bruno, L. Volterra \& R. Nicolett. (1993). "Chemical composition and biological origin of 'dirty sea' mucilages". Phytochemistry, 34(2),393395.

[12] R. Danovaro, S. Fonda Umani \& A. Pusceddu. (2009). "Climate change and the potential spreading of marine mucilage and microbial pathogens in the Mediterranean Sea". $\begin{array}{lll}P L O S & \text { ONE } & \text { 4(9): }\end{array}$ https://doi.org/10.1371/journal.pone.0007006

[13] V. Rouaud, N. Susperrégui, A. Fahy, R. Guyoneaud, S. Bichon, C. Liénart, Y. Del Amo, N. Savoye, P. Gaudin, R. Duran \& B. Lauga. (2019). "Dynamics of microbial communities across the three domains of life over an annual cycle with emphasis on marine mucilage in the Southern Bay of Biscay resolved by Microbial Fingerprinting". Continental
Shelf Research, 186,

https://doi.org/10.1016/j.csr.2019.06.003

[14] M. Monti, C. Welker, G. Dellavalle, L. Casaretto \& S. Fonda Umani. (1995). "Mucous aggregates under natural and laboratory conditions: a review". Science of the Total Environment, 165, 145-154.

[15] M. Mecozzi, M. Pietroletti \& M. E. Conti. (2008). "The Complex mechanisms of marine mucilage formation by spectroscopic investigation of the structural characteristics of natural and synthetic mucilage samples". Marine Chemistry, $112,38-52$.

[16] M. Mecozzi, M. Pietroletti, V. Gallo \& M. E. Conti. (2009). "Formation of incubated marine mucilages investigated by FTIR and UV-VIS spectroscopy and supported by TwoDimensional Correlation Analysis". Marine Chemistry, 116, $18-35$.

[17] N. J. Van Eck \& L. Waltman. (2011). "Text mining and visualization using VOSviewer". arXiv preprint arXiv:1109.2058.

[18] T. Huang, H. Wu, S. Yang, B. Su, K. Tang, Z. Quan, W. Zhong \& X. Luo. (2020). "Global trends of researches on sacral fracture surgery: a bibliometric study based on VOSviewer". Spine, 45(12), E721-E728.

[19] I. Hamidah, S. Sriyono \& M. N. Hudha. (2020). "A Bibliometric analysis of Covid-19 research using VOSviewer". Indonesian Journal of Science and Technology, 5(2), 209-216.

[20] T. Alcoverro, E. Conte \& L. Mazzella. (2000). "Production of mucilage by the adriatic epipelic diatom cylindrotheca closterium (bacillariophyceae) under nutrient limitation". Journal of Phycology, 36(6), 1087-1095.

[21] A. L. Alldredge \& K. M. Crocker. (1995). "Why do sinking mucilage aggregates accumulate in the water column?". Science of the Total Environment, 165(1-3), 15-22.

[22] F. Baldi,A. Minacci, A. Saliot, L. Mejanelle, P. Mozetic, V. Turk \& A. Malej. (1997). "Cell lysis and release of particulate polysaccharides in extensive marine mucilage assessed by lipid biomarkers and molecular probes". Marine Ecology Progress Series, 153, 45-57.

[23] A. W. Decho \& G. J. Herndl. (1995). "Microbial activities and the transformation of organic matter within mucilaginous material". Science of the Total Environment, 165(1-3), 33-42.

[24] A. Heissenberger, G. G. Leppard \& G. J. Herndl. (1996). "Ultrastructure of marine snow". II. Microbiological Considerations. Marine Ecology Progress Series, 135, 299308.

[25] G. G. Leppard. (1995). "The characterization of algal and microbial mucilages and their aggregates in aquatic ecosystems". Science of the Total Environment, 165(1-3), 103-131.

[26] E. Magaletti, R. Urbani, P. Sist, C. R. Ferrari \& A. M. Cicero. (2004). "Abundance and chemical characterization of extracellular carbohydrates released by the marine diatom cylindrotheca fusiformis under $\mathrm{N}$-and P-limitation". European Journal of Phycology, 39(2), 133-142.

[27] G. Michele, D. Tamara, D. Danilo, C. Stefano, S. Cosimo \& S. Fonda. (2012). "Recent changes in the marine ecosystems of the Northern Adriatic Sea". Esturine, Coastal and Shelf Science, 115, 1-13.

[28] S. M. Myklestad. (1995). "Release of extracellular products by phytoplankton with special emphasis on polysaccharides". Science of the Total Environment, 165(1-3), 155-164. 
[29] I. Obernosterer \& G. J. Herndl. (1995). "Phytoplankton extracellular release and bacterial growth: dependence on the inorganic N: P ratio". Marine Ecology Progress Series, 116(1), 247-257.

[30] G. Pletikapić, V. Žutić, I. Vinković Vrček \& V. Svetličić. (2012). "Atomic force microscopy characterization of silver nanoparticles interactions with marine diatom cells and extracellular polymeric substance". Journal of Molecular Recognition, 25(5), 309-317.

[31] A. Rinaldi, R. A. Vollenweider, G. Montanari, C. R. Ferrari \& A. Ghetti. (1995). "Mucilages in Italian Seas: the Adriatic and Tyrrhenian Seas, 1988-1991". Science of the Total Environment, 165(1-3), 165-183.

[32] D. C. Thornton. (2002). "Diatom aggregation in the sea: mechanisms and ecological implications". European Journal of Phycology, 37(2), 149-161.

[33] R. Zaccone, G. Caruso \& C. Cal1. (2002). "Heterotrophic bacteria in the northern Adriatic Sea: seasonal changes and ectoenzyme profile". Marine Environmental Research, 54(1), $1-19$. 